\title{
NOTES ON SYNONYMY OF SOME SOUTH ASIATIC MICROLEPIDOPTERA
}

\author{
BY \\ A. DIAKONOFF, F.R.E.S. \\ Zoölogisch Museum, Buitenzorg, Java \\ (Published with the permission of the Trustees of the British Museum)
}

The following notes on new synonymy of the species of South Asiatic Micro'epidoptera of the families Tortricidae, Phaloniidae, Eucosmilae and Glyphipterygidae were made during a visit to the British Museum, Natural History, London, in 1946 and chiefly concern the material in the extensive collection of the late E. MEYrick. A few additional new synonyms of Eucosmidae and of Carposinidae are not included and will be dealt with in another place.

We are greatly obliged to the Trustees of the British Museum for the opportunity to study these collections, and also to Mr. W. H. T. TAMs, of the Division of Lepidoptera of that Museum, for his kind help and suggestions.

\section{PHALONIIDAE}

Clysiana reliquatrix (Meyr.) I928.

Clysia ambiguella, Meyrick, Zoöl. Meded. Mus. Leiden $6: 145$, I921.

C'ysia reliquatrix Meyrick, 1928, Exot. Micr. $3: 436$.

Clysiana opisthodonta Diakonoff, I94I, syn. nov., Treubia I8 : 398, pl. I7, f. 3,5 .

When describing four Clysiana species from Java, the author misinterpreted MEYRICK's rather unsatisfactory description of the variable reliquatrix. His opistho'donta (lapsus for opistodonta) is a synonym of the latter, as the study of the genitalia revealed, while the species indicated by him as reliquatrix (t. c. : 399-340, pl. I7, f. 6-7), deserves a new name, for which he proposes Clysiana tenggerensis nom. nov.

\section{TORTRICIDAE}

\section{Zacorisca taminia (Feld.) 1875.}

Dichromia? taminia FELDER, Reise Novara, pl. I39, f. 29.

Atteria stephanitis Meyrick I9I0, syn. nov.; Trans. Ent. Soc. Lond. I9I0 : 433 . 
Zacorisca stephanitis, Meyrick, Lepid. Catal. 10 : 15, 1912. Gen. Insect. $149: 2$ i, pl. 3, f. 32, 1913. Diakonoff, Treubia $18: 402$, 1941.

Chresmarcha stephanitis, Diakonoff, Zoöl. Meded. Mus. Leiden 21 : I43 1939.

In the last above mentioned paper the author wrote: "Chresmarcha stephanitis Meyrick is without doubt a synonym of Dichromia taminia Felder et Rogenhofer, as the latter species is recorded from Java, where stephanitis Meyr. is very common. The above mentioned figures agree in all particulars, except for the colour of the head, thorax and abdomen, these being yellow in taminia and blue in stephanitis. As the illustrations in the book of Felder and Rogenhofer are handcoloured, the dark colours being used after the bright ones, it seems to me very probable, that the painter has forgotten to make head, thorax and abdomen of taminia blue! I did not succeed in finding the type specimen of taminia Feld. et Rog. and retain therefore Meyrick's name stephanitis, referring to his correct figure and description......" At present the author did find this type specimen, a $Q$, in the RothCHILD collection, transferred lately from Tring to the British Museum. Indeed its head, thorax and abdomen are deep blue! Which confirms our rather haphazard supposition. There is no reason to reject Felder's name any longer. The species can be recognised from the figure immediately, notwithstanding the fact, that its head and body are painted yellow. FELDER records the correct locality, Java, where in the mountains of the Western part of the island the females are not rare (however, we did not see a single male specimen from Java yet!); there occurs only one Zacorisca-species in Java. Moreover, FeldeR's type is at hand (cf. also our note on Enarmonia novarana Feld.).

Terthreutis sphaerocosma Meyr. 1918.

Terthreutis sphaerocosma Meyrick, Exot. Micr. 2 : 170.

Terthreutis duosticta Wileman \& Stringer 1929, 8yn. nov, Entomologist $62: 66$.

\section{Terthreutis xanthocycla (Meyr.) 1938.}

Amniodes xanthocycla Meyrick 1938 , Iris $52: 13$.

This species, which is closely related to $T$. bulligera Meyr., was described from China as genotype of a new genus Amniodes Meyr. which is syn. nov. of Terthreutis Meyr. 1918, Exot. Micr. 2 : 170, and belongs to the present family and not to Xylorictidae (Cryptophasidae), as MEYrICK thought. The unique specimen is in his collection.

Leontochroma antitona (Meyr.) 1927.

Rhapsodica antitona Meyrick, Exot. Micr. $3: 364$. 
The unique specimen in MEYRICK's collection from Sumatra is rather worn and has turned pale. antitona represents the genotype of the genus Rhapsodica Meyr., which was placed in the family $X y$ lorictidae. This is, however, a syn, nov. of Leontochroma Wals. 1900, Ann. Mag. Nat. Hist. (7) $5: 466$ and belongs to Tortricidae accordingly.

\section{EUCOSMIDAE}

\section{Cryptaspasma lugubris (Feld.) 1875 .}

Penthina? lugubris Felder, Reise Novara, Lep. 5 : pl. I38, f. $3^{2}$.

Cryptaspasma lugubre, Walsingham, Ann. Mag. Nat. Hist. (7), $5: 463$, 1900.

Notocelia helota Meyrick 1905, J. Bomb. Nat. Hist. Soc. $16: 587$.

Eucosma brachyptycha Meyrick I9I I, syn. nov., Proc. Linn. Soc. N.S. Wales $36: 246$.

Acharnaeodes helota, Meyrick, Ann. S. Afric. Mus. $23: 327$, 1926.

Idiographis zophocosma Meyrick I93I, syn. nov., Exot. Micr. 4 : I59.

The type of zophocosma (unique) in the National Collection is labelled: "Hysterosia zophocosma" (fam. Tortricidae). The identity of this species is stated by Walsingham (I900); he writes: “"794 (I). Cryptaspasma lugubre, F. \& R... Felder and Rogenhofer record their type of Penthina? lugubris from "fl. Amazonas (Bates)". The specimen is labelled " 276 " and "B. in cop." It is on a long iron pin, whereas Bates used short English pins, and the evidence is very strong that this is another of the very numerous mistakes in locality-labels which pervade the collection ostensibly made by the "Novara" expedition, but which was obviously put together by purchase and otherwise from many widely scattered sources. The specimens labelled Bates Coll. could have been obtained in no other manner, as Mr. Bates did certainly not accompany the expedition" ". FeldeR's figure is reasonably good. His type specimen is in the National Collection in the British Museum. The author sees no reason in rejecting Felder's name. Walsingham records this species from N. Bengal, Sikkim, Assam, Perak and Batian. It is known to the author also from Sumatra.

\section{Argyroploce discana (Feld.) 1875.}

Tortrix? discana Felder, Reise Novara, Lep. 5: pl. I37, f. 4I. MeYrick, Proc. Linn. Soc. N.S. Wales $36: 280$, I9 I I.

Eucosma leucaspis Meyrick I902, syn. nov., in Gardiner, Fauna Maldives: 126. Fletcher, Mem. Agr. Ind., Ent. $6: 60$, pl. I3, f. 2, 1920.

Platypeplus rhynchias Meyrick, I905, syn. nov., J. Bomb. Nat. Hist. Soc. $16: 586$. Fletcher, Mem. Agr. Ind., Ent. $6: 61$, 1920.

Argyroploce peltastica Meyrick; I921, syn. nov, Ann. Transv. Mus. 8 : 57.

The sexual dimorphism of this species is responsible for the above.mentioned 
confusion, as the male has a pitch-black spot in disc of hind wing (discana and rhynchias), while this spot is lacking in the female (leucaspis, peltastica).

Argyroploce semiculta Meyr. I909.

Argyroploce semiculta Meyrick; J. Bomb. Nat. Hist. Soc. I9 ; 604. Exot. Micr. 2 : 20, 19i6. Fletcher, Mem. Agr. Ind., Ent. 6 : 61, 1920.

Argyroploce heteraspis Meyrick 1936, syn. nov, Exot. Micr. 4 :6r4.

\section{Argyroploce harmonica (Meyr.) I905.}

Platypeplus harmonica Meyrick, J. Bomb. Nat. Hịst. Soc. I6 : 584 .

Argyroploce philocompsa Meyrick I921, syn. nov., Zoöl. Meded. Mus. Leiden, $6: 158$.

\section{Argyroploce strepsibathra Meyr. 1928.}

Argyroploce strepsibathra Meyrick, Exot. Micr. $3: 446$. Argyroploce tetraploca Meyrick, 1928, syn. nov., t.c.: 446.

\section{Argyroploce confertana (Walk.) 1863.}

Grapholitha confertana Walker, Cat. Lep. Het. B. M. $28: 388$. WalsinghaM in Moore, Lep. Ceylon, $3: 495$, I887, Meyrick, Trans. Linn. Soc. N.S. Wales $36: 378$, 1911 .

Grapholitha vulgana Walker I866, Cat. Lep. Het. B. M. 35 : 1796.

Argyroploce claviculata Meyrick 1909, J. Bomb. Nat. Hist. Soc. 19 : 600. Argyroploce onychosema Meyrick I93I, syn. nov, Exot. Micr. 4 : 134.

\section{Argyroploce herbifera Meyr. Ig09.}

Argyroploce herbifera Meyrick, J. Bomb. Nat. His. Soc. I9:603. Argyroploce hygrargyra Meyrick 1931, syn. nov, Exot. Micr. 4 : 137.

\section{Argyroploce albitibiana (Snell.) I901.}

Grapholitha albitibiana Snellen, Tijd. v. Ent. $44: 69$, pl. 5. f. 2. Platypeplus crescerias Meyrick 1905, J. Bomb. Nat. Hist. Soc. $16: 585$. Argyroploce inodes Meyrick 19I I, Proc. Linn. Soc. N.S. Wales 36 : 269. Argyroploce conchifera Meyrick 1931, syn. nov., Exot. Micr. 4 : I3O.

\section{Eucosma falcana (Wals.) 1900.}

Eucelis? falcana Walsingham, Ann. Mag. Nat. Hist. (7) $6: 407$. Eucelis ochreocervina Walsingham 1000, syn. nov., t. c.: 407-408. 
Eucosma trophiodes Meyrick 1908, syn. nov., J. Bomb. Nat. Hist. Soc I8:6r3.

Eucosma melanaula Meyrick 1916, syn. nov., Exot. Micr. 2 : I7. FLETCHER, Mem. Agr. Ind., Ent. $6: 49$, pl. 1o, f. I and pl. II, 1920.

Procoronis swinhoeana (Wals) 1890.

Semasia swinhoeana Walsingham, Trans: Ent. Soc. Lond. 1890 : 294, pl. 8 f. 19 .

Procoronis rhotias Meyrick I9I I, syn. nov., Proc. Linn. Soc. N.S. Wales $36: 251$.

\section{Enarmonia novarana (Feld.) 1875.}

Grapholitha novarana Felder, Reise Novara, Lep. 5 : pl. 137, f. 49. MEYRICK, Exot. Micr. 5 : 99, 137.

Copromorpha cymbalora Meyrick 1907, J. Bomb. Nat. Hist. Soc. I8: 152.

Laspeyresia cymbalora, Meyrick, Exot. Micr. 5 : 99, 1937. Trans. Ent. Soc. Lond. $89: 5^{2}$. Fletcher, l.c.: 52 (note).

In the last above mentioned paper Meyrick writes: "Laspeyresia cymbalora Meyrick, Grapholitha novarana Feld. Reis. Nov. pl. CXXXVII, 49 (Nicobars) is a synonym of this, according to the type specimen (fragmentary, with one pair of wings, palpi and antennae missing), kindly sent me for study from the Vienna Museum. I cannot, however, adopt Felder's name, as his plate shows the basal halves of the forewings and hindwings as blackish, whereas they are really clear white, and the colouring of the rest of the forewings unrecognisable, whilst the erroneous plates (of which the pigments must have changed with age) are unaccompanied by any corrective description". The author cannot agree with this conclusion. There are different copies of FELDER's atlas. In the copy in his possession novarana is reproduced so well, that it can be recognised at once, the only fault being the colour of the body and the basal parts of the wings: yellow and orange, instead of white. The markings on the rest of the fore wings are correct, orange on a dark grey ground, and agree very well with MEYRICK's description of cymbalora. As I) the locality is reconded correctly, 2) the type is still available and 3) this very distinct and conspicuous Eucosmid cannot be taken easily for any other Enarmonia species, there is no reason to reject FELDER's name. A coloured figure is much more useful for a correct identification of an insect than many a short and inadequate Linnean or Fabrician description. And once beginning with rejecting FELDER's names because of incorrect details of his otherwise very nice figures, where would we be with all the impossible descriptions of old authors, which "validate" numberless names? A considerable difficulty would also arise at the choice of the criteria for the discrimination of FELDER's valid and invalid names. 


\section{Enarmonia pseudonectis (Meyr.) 1907.}

Laspeyresia pseudonectis Meyrick, J. Bomb. Nat. Hist. Soc. 18 : I46. FLETCHER, Mem. Agric. Ind., Ent. 6 :66, pl. 15, 1020.

Laspeyresia ptychora Meyrick 1907, syn. nov., J. Bomb. Nat. Hist. Soc. I8 : I47; 1.c. 22 : 288, I9ı I. Fletchę, Mem. Agr. Ind., Ent. $6: 63$, 1920.

\section{Enarmonia delectana (Snell.) I90I.}

Gapholitha delectana Snellen, Tijd. v. Ent. $44: 72$, pl. 5, f. I.

Laspeyresia haemograpta Meyrick I928, syn. nov., Exot. Micr. $3: 45^{\text {I-4-42. }}$

\section{Enarmonia koenigana (Fabr.) I794.}

Pyralis koenigana Fabricius, Entom. System., 3, pars 2 : 279.

Hemerosia aurantiana Pryer, Cist. Ent. 2 :235, pl. 4 f. 12, (1875-82).

Coptoloma aurantiana, Swinhoe, in Cotes \& Swinhoe, List Moths Ind.: $699,1887$.

Laspeyresia aurantiana, Meyrick, Proc. Linn. Soc. N.S. Wales 36:392, I9I I.

Eucelis vulnerata Walsingham 1900, in Swinhoe, Cat. Lep. Het. Mus. Oxon. $2: 57 \mathrm{I}$.

Laspeyresia koenigana, Fletcher, S. Ind. Ins. : 450, f. 328, 1914. Mem. Agr. Ind., Ent. $6: 62$, I920.

MEYRICK erroneously regarded delectana Snell. as a synonym of this.

Enarmonia hemicosma (Low.), 1908.

Leptarthra hemiscosma Lower, Trans. R. Soc. South Australia I908 : 321 .

Laspeyresia exemplaris Meyrick I9I r, syn. nov, Pr. Linn. Soc. N.S. Wales $36: 396$.

\section{GLYPHIPTERYGIDAE \\ Irianassa speciosana (Pag.) 1900.}

Grapholitha speciosana Pagenstecher, Zoologica 29 : 225.

Mictopsichia speciosana, Durrant, in collection.

Irianassa alcyonopa Meyrick 1926. syn. nov, Exot. Micr. 3 : 301.

Imma mormopa Meyr. I9Io.

Imma mormopa Meyrick, Trans. Ent. Soc. Lond. 19Io : 467.

Simaethis nubicincta Meyrick 1938, syn. nov, Iris $52: 86$.

Tortyra divitiosa (Walk.) I864.

Saptha divitiosa Walker, Cat. Lep. Het. B. M. 30 : 1015.

Tortyra divitiosa, Meyrick, Proc. Linn. Soc. N.S. Wales $32: 99,1907$. 
Badera prodigella Walker I866, syn. nov., Cat. Lep. Het. B. M. 35 : 1820. Badera nobilis Felder I875, Reise Novara, Lep. 5 : pl. 129, f. 9.

Choregia striana Snellen I885, Tijd. v. Ent. 28 : I7.

Tortyra prodigella, Meyrick, Proc. Linn. Soc. N.S. Wales 32 : 100, 1907.

Tortyra pretiosa (Walk.) 1866.

Badera pretiosa Walker, Cat. Lep. Het. B. M. 35 : I819.

Choregia basalis Snellen 1885, Tijd. v. Ent. $28: 18$.

Tortyra bery!litis Meyrick I910, syn. nov., Trans. Ent. Soc. Lond. 1910: 462.

Anthophila dichlora (Meyr.) I912.

Simaethis dichlora Meyrick, Exot. Micr. I : 48.

Simaethis pilaria Meyrick I912 syn. nov., t. c. : 50. 